\title{
Application of the IS-MP-IA Model and the Taylor Rule to Croatia: Policy Implications for Economic Integration
}

\author{
Yu Hsing \\ Southeastern Louisiana University
}

\begin{abstract}
Applying the IS-MP-IA model and the Taylor rule, this study finds that a lower expected inflation rate, real appreciation, a lower federal funds rate, and more world output would help increase the Croatian output. The insignificance of government deficit spending suggests that the Ricardian-equivalence hypothesis may be applicable to Croatia. The conventional wisdom to pursue currency devaluation to stimulate the economy may not work for Croatia.
\end{abstract}

- JEL classifications: E52, E62, F41

- Key words: IS-MP-IA, Taylor rule, deficit spending, devaluation, world interest rates

\section{Introduction}

Like most other countries in the region, Croatia has experienced great challenges and made progress in its transition to a market economy. The central government has attempted to pursue fiscal discipline as evidenced by the primary budget deficit/ GDP ratio of 2.9 per cent in 2002 and 4.2 per cent in 2003 and the general government debt/GDP ratio of 41.5 per cent in 2003 . The money market rate declined to 3.31 per cent in 2003 compared with the U.S. federal funds rate of 1.13 per cent and Euro rate of 1.22 per cent. It may suggest that the Croatian National Bank (CNB) followed world interest rates in determining the domestic interest rate

\footnotetext{
*Corresponding address: Charles Blackwell Endowed Professor of Economics, Head, Department of General Business - SLU 10813, College of Business, Southeastern Louisiana University, Hammond, LA 70402 USA. Tel: +1-985-549-2086, Fax: +1-985-549-2881, E-mail: yhsing@selu.edu (2006-Center for International Economics, Sejong Institution, All Rights Reserved.
} 
policy in order to continue attracting foreign investors and make the cost of borrowing affordable. The annual inflation rate reached the worst level of 1,502.17 per cent in 1993 and then declined considerably to 1.70 per cent in 2002 and 0.12 per cent in 2003, indicating that monetary policy in maintaining price stability has been effective in recent years as evidenced by the decline in the growth rate for monetary base from 994.15 per cent to 23.95 per cent during 1993-2003. The exchange rate defined as kunas per U.S. dollar rose from 0.80 in 1992 to 6.56 in 1993, reached a high of 8.36 in 2001, and then declined to 6.12 in 2003. These statistics suggest that the currency had appreciated since 2001 and may affect net exports and capital flows. The growth rates of 5.22 per cent in 2002 and 4.26 per cent in 2003 show that its macroeconomy performed reasonably well.

The International Monetary Fund (2004) assessed the Croatian economy and made some comments. It is appropriate to pursue a stable exchange rate policy and allow its fluctuations within 4.5 per cent of the average since 1999. The relatively weak transmission mechanism from the policy rates, the discount rate or the money market rate that the Croatian National Bank can control, to the lending rate and advanced currency substitution need to be considered in the study of monetary policy. To introduce open market operations would enhance the capital market. The govern-ment is expected to maintain fiscal transparency, improve the welfare program, broaden the tax base and reduce tax burdens on labor and capital, reduce subsidies, increase the proportion of domestic sources of financing government deficit to $1 / 3$ of the total to reduce the risk of depreciation, and reduce government deficit by 0.5 percentage points per year. Stringent labor laws need to be amended to create more job opportunities. Furthermore, the government needs to keep the pension system sustainable, pursue reforms in public enterprises, and speed up privatization in the railways, utilities, telecommunications, and insurance sectors,

Several recent studies of Croatia and some of countries in the region examined monetary policy (Dragic, 1999; Bozina, Matulich, and Skare, 2003; Craft, 2003), inflation dynamics (Payne, 2002), determinants of economic growth (Bujas, 2001), exchange rate pass-through, movements, or overvaluation or devaluation (Halpern and Wyplosz, 1995; Billmeier and Bonato, 2004), possible adoption of the euro (Watson, 2004), development of EMU and Croatia (Nikolic and Pecaric, 1997), legal system, financial environment and institution (Glogovsek, 1997), among others.

In light of the application for an EU member, the expectation to follow the EU criteria, and the pursuit for a stable and growing economy, it is significant to examine 
short-term output fluctuations in Croatia. First, to the author's knowledge, none of the previous studies employed the IS-MP-IA model (Romer, 2000) in specifying the relationships among major macroeconomic variables. Second, the IS function is extended to include the real exchange rate and world output. Third, the monetary policy function (Taylor, 1993, 1998, 1999) is extended to include the exchange rate and the world interest rate. It would be reasonable to assume that a small open economy with imperfect capital mobility would use monetary policy to maintain currency stability and follow the trend of world interest rates to attract investors and avoid large amount of capital outflows.

\section{Theoretical Model}

Suppose that the consumption function is determined by disposable income and the real interest rate, that investment spending is a function of output and the real interest rate, that net exports are a function of domestic output, world output, and the real effective exchange rate, and that the monetary policy function is influenced by the inflation gap, the output gap, the exchange rate gap, and the world interest rate. Extending the IS-MP-IA model (Romer, 2000) and the Taylor rule (1993, 1998, 1999), we can write the IS, MP (monetary policy), and IA (inflation adjustment) functions as

$$
\begin{gathered}
Y=C(Y-T, R)+I(Y, R)+G+N Y\left[Y, W Y, e\left(P^{*} / P\right)\right] \\
R=R\left(\pi-\pi^{*}, Y-Y^{*}, e-e^{*}, R^{W}\right) \\
\pi=\pi^{e}+\theta\left(Y-Y^{*}\right)+\lambda e
\end{gathered}
$$

where

$Y=$ real GDP for Croatia,

$C=$ consumption spending,

$T=$ government tax revenues,

$R=$ the real interest rate,

$I=$ investment spending,

$G=$ government spending,

$N X=$ net exports, 
$W Y=$ world output,

$e=$ the nominal effective exchange rate (an increase is an appreciation),

$P^{*}=$ the price level in Croatia,

$P=$ the trade-weighted price level in selected countries,

$\pi=$ the inflation rate,

$\pi^{*}=$ the target inflation rate,

$Y^{*}=$ potential output,

$e^{*}=$ the target exchange rate,

$R^{W}=$ the world interest rate, and

$\pi^{e}=$ the expected inflation rate.

Suppose that a higher real interest rate would reduce household consumption spending, that currency appreciation would hurt next exports, that more world output would help net exports, and that the interest rate determined by the Croatia National Bank would react positively to a higher inflation rate, more output and the world interest rate and negatively to exchange rate appreciation. Assume that (1), (2) and (3) have continuous partial derivatives. Let

$$
\begin{aligned}
& C_{Y}>0, C_{R}<0, I_{Y}>0, I_{R}<0, N X_{Y}>0, N X_{W Y}>0, N X_{e}<0, \\
& R_{\pi}>0, R_{Y}>0, R_{e}<0, R^{R^{W}}>0, \pi_{Y}>0, \pi_{e}<0 .
\end{aligned}
$$

The slopes of equations (1) and (2) are given by equations (4) and (5), respectively

$$
\begin{gathered}
\left.\frac{d R}{d Y}\right|_{I S}=\frac{1-C_{Y}-I_{Y}-N X_{Y}}{-\left(C_{R}+I_{R}\right)}<0 \\
\left.\frac{d R}{d Y}\right|_{M P}=-\frac{R_{Y}}{1}>0
\end{gathered}
$$

The endogenous-variable Jacobian is given by

$$
|J|=\left(1-C_{Y}-I_{Y}-N X_{Y}\right)-\theta R_{\pi}\left(C_{R}+I_{R}\right)-R_{Y}\left(C_{R}+I_{R}\right)>0 .
$$

Applying the implicit-function theorem and solving for three unknowns $Y, R$, and $\pi$, equilibrium output $\tilde{Y}$ is given by

$$
\bar{Y}=\bar{Y}\left[\pi^{e}, G, T, e\left(P^{*} / P\right), W Y ; \theta, \lambda, \pi^{*}, Y^{*}, e^{*}\right]
$$


Applying comparative static-analysis, the impact of a change in the nominal effective exchange rate on equilibrium output is given by

$$
\begin{aligned}
& \frac{\partial \bar{Y}}{\partial e}=\frac{N X_{e}\left(P^{*} / P\right)+\lambda R_{\pi}\left(C_{R}+I_{R}\right)+R_{e}\left(C_{R}+I_{R}\right)}{|J|} \\
& >0 \text { if }\left|N X_{e}\left(P^{*} / P\right)\right|<\left|\lambda R_{\pi}\left(C_{R}+I_{R}\right)+R_{e}\left(C_{R}+I_{R}\right)\right| \\
& >0 \text { if }\left|N X_{e}\left(P^{*} / P\right)\right|>\left|\lambda R_{\pi}\left(C_{R}+I_{R}\right)+R_{e}\left(C_{R}+I_{R}\right)\right|
\end{aligned}
$$

Hence, the appreciation of the kuna would raise (reduce) output if the positive impact of increased consumption and investment spending caused by a lower inflation rate and interest rate is greater (less) than the negative effect of decreased net exports. Bahmani-Oskooee and Miteza (2003) reviewed many previous articles and indicated that the influence of currency devaluation on output is unclear, depending upon the specification of a model, the country under study, the time period, the methodology employed in empirical work, and other factors. The impact of a change in the expected inflation rate or the world interest rate on equilibrium output is given by (8) and (9), respectively

$$
\begin{gathered}
\frac{\partial \bar{Y}}{\partial \pi^{*}}=\frac{R_{\pi}\left(C_{R}+I_{R}\right)}{|J|}<0 \\
\frac{\partial \bar{Y}}{\partial R^{W}}=\frac{R_{R^{W}}\left(C_{R}+I_{R}\right)}{|J|}<0
\end{gathered}
$$

A higher expected inflation rate would shift the inflation adjustment curve upward, raise the actual inflation rate, cause the central bank to raise the real interest rate, and reduce consumption and investment expenditures. When the world interest rate rises, the central bank is likely to respond in a similar manner in order to follow the trend.

To avoid a high degree of multicollinearity, real government deficit spending defined as $\mathrm{D}=(\mathrm{G}-\mathrm{T}) / \mathrm{CPI} * 100$ is used in empirical work. The sign of budget deficit may be positive, uncertain or neutral in the long run due to the Ricardianequivalence hypothesis (Barro, 1989; Ramsey and Shapiro, 1998; Blanchard and Perotti, 1999; Taylor, 2000; Burnside, Eichenbaum and Fisher, 2000). 


\section{Empirical Results}

The sample ranges from 1994.Q1 to 2004.Q1. Real GDP is an index number with 2000 as the base year. Numerical values for real GDP are not used because the data began in 1997.Q1. The expected inflation rate $\pi^{e}$ is the lagged inflation rate. Real government deficit is expressed in million kunas. The real effective exchange rate $\varepsilon$ is equal to trade-weighted foreign currencies per kuna adjusted for relative prices. $\varepsilon$ is constructed by the IMF and includes major currencies such as the U.S. dollar, the euro, the British pound, and the Japanese yen. Hence, an increase in $\varepsilon$ is real appreciation, and vice versa. The world interest rate is represented by the U.S. federal funds rate due to its significant influence worldwide. World industrial output for industrialized countries is chosen to represent world output. An analysis of real GDP shows that there are strong seasonal effects. Hence, three binary variables - Q1, Q2, and Q3 - are included in the regression. Variables are measured in the logarithmic scale except for the expected inflation rate, real deficit spending, and the binary variables due to zero or negative values.

Unit root tests show that $Y, \varepsilon, R^{W}$ and $Y W$ have unit roots in levels, $\pi^{e}$ and $D$ are stationary in levels, and all the variables are stationary in first difference at the $5 \%$ level. Applying the Johansen test, the null hypothesis of a zero cointegrating versus the alternative of one cointegrating relationship can be rejected because the trace statistic of 174.14 is greater than the critical value of 95.75 and because the $\lambda$-max value of 78.76 is greater than the critical value of 40.08 at the 5 per cent level. Hence, these variables have a long-term stable relationship.

The estimated regression and related statistics are presented in Table 1. The firstdifference form is not used because the long-term relationship may be obscured (Greene, 2003). All the coefficients in the regression are significant at the 1 per cent or 5 per cent level except that the coefficient of real government deficit spending is insignificant at the 10 per cent level and that the coefficient of Q2 is significant at the 10 per cent level. Equilibrium output is negatively influenced by the expected inflation rate and the U.S. federal funds rate and positively affected by real exchange rate appreciation and world output. Equilibrium output in logarithm would decline by 0.003 if the expected inflation rate rises one percentage point. If the real effective exchange rate rises by 1 per cent, real GDP would increase by 0.464 per cent. An increase in world output by 1 per cent is expected to raise output by 1.113 per cent. Attempts were made to find Johansen's maximum likelihood estimate of the cointegrating vector without success due to near singular 
Table 1. Estimated Regression of Equilibrium GDP for Croatia

Dependent Variable: LOG $(\bar{Y})$

Method: Least Squares

Sample(adjusted): 1994:1 2004:1

Included observations: 41 after adjusting endpoints

Newey-West HAC Standard Errors \& Covariance (lag truncation=3)

\begin{tabular}{lcccc}
\hline \multicolumn{1}{c}{ Variable } & Coefficient & Std. Error & t-Statistic & Prob. \\
\hline C & -2.517275 & 0.494481 & -5.090740 & 0.0000 \\
$\pi^{e}$ & -0.000274 & 0.000125 & -2.185612 & 0.0363 \\
D & $-5.32 \mathrm{E}-06$ & $3.22 \mathrm{E}-06$ & -1.651142 & 0.1085 \\
LOG $(\varepsilon)$ & 0.463600 & 0.116297 & 3.986357 & 0.0004 \\
LOG $\left(R^{W}\right)$ & -0.073216 & 0.006978 & -10.49219 & 0.0000 \\
LOG $(W Y)$ & 1.112937 & 0.064508 & 17.25261 & 0.0000 \\
Q1 & -0.042457 & 0.010410 & -4.078274 & 0.0003 \\
Q2 & 0.018330 & 0.010334 & 1.773728 & 0.0856 \\
Q3 & 0.096928 & 0.009412 & 10.29850 & 0.0000 \\
\hline R-squared & 0.970154 & Mean dependent var & 4.581985 \\
Adjusted R-squared & 0.962692 & S.D. dependent var & 0.108795 \\
S.E. of regression & 0.021014 & Akaike info criterion & -4.696066 \\
Sum squared resid & 0.014131 & Schwarz criterion & -4.319916 \\
Log likelihood & 105.2693 & F-statistic & 130.0198 \\
Durbin-Watson stat & 1.612194 & Prob(F-statistic) & 0.000000 \\
\hline Notes:
\end{tabular}

Notes:

$\bar{Y}$ is equilibrium real GDP.

$\pi^{e}$ is the lagged inflation rate.

$D$ is real government deficit spending.

$\varepsilon$ is real effective exchange rate. An increase is real appreciation.

$R^{W}$ is the U.S. federal funds rate.

$W Y$ is world industrial output.

matrix.

Several comments can be made. The insignificant coefficient for government deficit spending suggests that Croatia's efforts to reduce budget deficits in the long run are appropriate. Because real exchange rate appreciation would help raise output, the conventional approach to devalue a currency to stimulate the economy would not apply to Croatia. The CNB would be rational to change the domestic interest rate in response to the world interest rate in order to avoid large fluctuations in the net capital outflow. The relatively low interest rate, which was initiated by the Federal Reserve Bank in the U.S., is expected to stimulate consumption and investment spending in Croatia. Lastly, the Croatian economy will be helped by a stronger world economy since its international trade plays an increasing role in its 
economic growth.

\section{Summary and Conclusions}

In this paper, the author has applied IS-MP-IA model (Romer, 2000) and the Taylor rule $(1993,1998,1999)$ to examine the impacts of changes in selected macroeconomic variables on real output for Croatia. Empirical outcomes suggest that the IS-MP-IA model seems to work well. A lower expected inflation rate, a higher real effective exchange rate, a lower world interest rate, and more world output are expected to increase equilibrium output for Croatia. There are several policy implications. The CNB plays a significant role in determining the directions and magnitude of output fluctuations when the economy responds to a change in any of the right-hand side variables. More world output or a lower world interest rate leading to a lower domestic interest rate would help the Croatian economy because it would stimulate household consumption, business investment expenditures, and net exports. The positive effect of real appreciation on the Croatian output may be attributable to the benefits of lower import prices, lower domestic inflation, inflows of capital, and other factors.

There may be areas for future research. If the number of observations for stock values is available and large enough, the model may include stock values in order to estimate the potential wealth effect and balance-sheet channel (Mishkin, 1995; Kuttner and Mosser, 2002). Some of the relationships in the money demand function cannot be analyzed due to the use of the monetary policy function. The expected inflation rate may be estimated in different manners.

Received 10 March 2005, Accepted 14 September 2005

\section{References}

Bahmani-Oskooee, M. Miteza, I. (2003) "Are Devaluations Expansionary or Contractionary? A Survey Article," Economic Issues, 8, 1-28.

Barro, R. J. (1989) "The Ricardian Approach to Budget Deficits," Journal of Economic Perspectives, 3, 37-54.

Blanchard, O. Perotti, R. (1999) "An Empirical Characterization of the Dynamic Effects of Changes in Government Spending on Output," NBER Working Paper Number 7296.

Billmeier, A. Bonato, L. (2004) "Exchange Rate Pass-Through and Monetary Policy in 
Croatia," Journal of Comparative Economics, 32, 426-444.

Borensztein, E. Zettelmeyer, J. Philippon, T. (2001) "Monetary Independence in Emerging Markets: Does the Exchange Rate Regime Make a difference," IMF Working Paper: WP/01/01.

Bozina, L. Matulich, S. Skare, M. (2000) "Croatian Monetary Sovereignty," Ekonomska Istrazivanja/Economic Research, 13, 1-11.

Bujas, G. (2001) "Determinants of Economic Growth with Reference to Transitional Countries," Zbornik Radova Ekonomskog Fakulteta U. Rijeci/Proceedings of Rijeka School of Economics: Journal of Economics and Business, 19, 19-29.

Burnside, C. Eichenbaum, M. Fisher, J. D. M. (2000) "Assessing the Effects of Fiscal Shocks," NBER Working Paper Number 7459.

Davidson, R. and J. G. MacKinnon (1985) "Testing Linear and Log-Linear Regressions against Box-Cox Alternatives," Canadian Journal of Economics 18, 499-517.

Dragic, K. "ESCB Monetary Policy Operations and Croatian Approach to EMU,"

Zbornik Radova Ekonomskog Fakulteta U. Rijeci/Proceedings of Rijeka School of Economics: Journal of Economics and Business 17, 1999, 95-108.

Edwards, S. (1986) "Are Devaluations Contractionary," Review of Economics and Statistics 68, 501-508.

Glogovsek, J. (1997) "Economic System of European Union and Adjustment of the Republic of Croatia," Zbornik Radova Ekonomskog Fakulteta U. Rijeci/Proceedings of Rijeka School of Economics: Journal of Economics and Business 15, 87-94.

Greene, W. (2003). Econometric Analysis. Upper Saddle River, New Jersey: Prentice Hall.

Halpern, L. and C. Wyplosz (1995) "Equilibrium Real Exchange Rates in Transition," Centre for Economic Policy Research, Discussion Paper: 1145.

Kraft, E. (2003) "Monetary Policy under Dollarisation: The Case of Croatia," Comparative Economic Studies 45, 256-277.

Kuttner, K. N. and P. C. Mosser (2002) "The Monetary Transmission Mechanism: Some Answers and Further Questions," FRBNY Economic Policy Review 8, 15-26.

International Monetary Fund "Republic of Croatia: 2004 Article IV Consultation and Request for Stand-By Arrangement-Staff Report; Public Information Notice and Press Release on the Executive Board Discussion; and Statement by the Executive Director for the Republic of Croatia," IMF Country Report No. 04/253, September 2004.

Mishkin, F. S. (1995) "Symposium on the Monetary Transmission Mechanism," Journal of Economic Perspectives 9, 3-10.

Nikolic, N. and M. Pecaric (1997) "The Implication of Development of the European Monetary Union on Croatian Economy," Zbornik Radova Ekonomskog Fakulteta U. Rijeci/ Proceedings of Rijeka School of Economics: Journal of Economics and Business 15, 110-116.

Payne, J. E. (2002) "Inflationary Dynamics of a Transition Economy: The Croatian Experience," Journal of Policy Modeling 24, 219-230. 
Ramsey, V. and M. Shapiro (1998) "Costly Capital Reallocation and the Effects of Government Spending," Carnegie Rochester Conference Series on Public Policy 48, 145194.

Romer, D. (2000) "Keynesian Macroeconomics without the LM Curve," Journal of Economic Perspectives 14, 149-169.

Taylor, J. B (1993) "Discretion versus Policy Rules in Practice," Carnegie-Rochester Conference Series on Public Policy 39, 195-214.

Taylor, J. B. (1995) "The Monetary Transmission Mechanism: An Empirical Framework," Journal of Economic Perspectives 9, 11-26.

Taylor, J. B. (1998) "Applying Academic Research on Monetary Policy Rules: An Exercise on Translational Economics," Manchester School, Supplement, 1-16.

Taylor, J. B. (1999) "Monetary Policy Rules: Introduction," Taylor, John B., ed., Monetary Policy Rules, NBER Conference Report series. Chicago and London: University of Chicago Press, 1-14.

Taylor, J. B. (2000) "Reassessing Discretionary Fiscal Policy," Journal of Economic Perspectives, 14, 21-36.

Watson, C. M. (2004) "Adopting the Euro: An Introduction to Four Country Studies," Comparative Economic Studies, 46, 95-103. 